
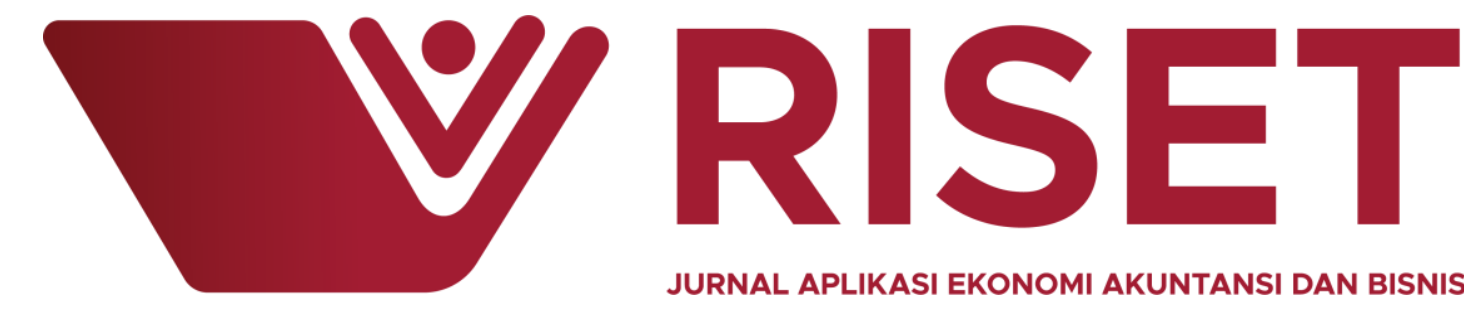

JURNAL APLIKASI EKONOMI AKUNTANSI DAN BISNIS

\title{
Analisis Akuntansi Untuk Likuidasi Korporasi Pada Reksa Dana Terproteksi Tram Terproteksi Prima Xi
}

\author{
Ahmad Gufron ${ }^{1)}$, Amrie Firmansyah ${ }^{2)}$, Firman Anugrah Firdaus ${ }^{3)}$ \\ 1,2,3) Politeknik Keuangan Negara STAN
}

https://doi.org/10.35212/277626

\section{INFO ARTIKEL}

\section{ABSTRACT}

Analisis Akuntansi Untuk Likuidasi Korporasi Pada Reksa Dana Terproteksi Tram Terproteksi Prima Xi

Submitted: 20 JANUARI 2019 Revised: 15 FEBRUARI 2019 Accepted : 23 MARET 2019

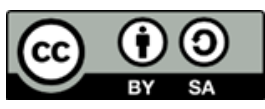

The Imposed Statement of Financing Accounting Standards in Indonesia allow an entity to use another accounting basis other than going concept base when management intends to liquidate the entity or discontinue the trading (PSAK 1, 2015). This study aims to discuss the implementation of accounting standard and the procedures applied by the Reksa Dana Terproteksi TRAM Terproteksi Prima XI management related to its liquidation. This study employs a qualitative approach with using data of TRAM Terproteksi Prima XI's Audited Financial Statement 31 December 2015 (Liquidation Base) and 2014 (Business Continuity Base) and for the years on that date and Reksa Dana Terproteksi TRAM Terproteksi Prima XI's Prospectus. Therefore, it could be seen the relation to the imposed accounting standard and liquidation procedures regulated in Indonesia.

This study concludes that Reksa Dana Terproteksi TRAM Terproteksi Prima XI apply FASB Accounting Standards Codification Topic 205 on Liquidation Basis of Accounting in the liquidation process. Also of terms of corporate liquidation procedures, Reksa Dana Terproteksi TRAM Terproteksi Prima XI implements more detailed procedures that the Act number 47 of 2007 which only regulates the procedure of liquidation in practice. It could be seen from Reksa Dana Terproteksi TRAM Terproteksi Prima XI's Prospectus which further explains the obligations of investment managers in the liquidation process compared to the role of the liquidator itself and reporting the results of liquidation and the distribution of proceeds of liquidation to the Financial Services Authority.

Keywords : Liquidation Base, Going Concern, Accounting Standards,

Email : ahmadgufron646@gmail.com ${ }^{1)}$, amrie.firmansyah@gmail.com ${ }^{2)}$, firmananugrahfirdaus@gmail.com ${ }^{3)}$ 


\section{PENDAHULUAN}

Korporasi atau Perseroan Terbatas (PT) merupakan salah satu bentuk badan usaha yang lazim dipilih oleh masyarakat dalam menjalankan kegiatan bisnisnya. Sampai dengan tahun 2016, tercatat sebanyak 172.682 perusahaan yang memilih korporasi sebagai bentuk badan usahanya (Badan Pusat Statistik, 2016). Salah satu karakteristik utama korporasi adalah pemilik usaha dan badan usaha yang dimilikinya merupakan entitas yang terpisah secara hukum (separate legal entity). Dengan demikian, berlaku prinsip separate patrimony, yaitu pemisahan kepemilikan aset antara pemilik usaha dan badan usaha, serta prinsip limited liability, di mana tanggung jawab pemilik usaha hanya sebatas jumlah saham yang dimilikinya (Kraakman et al., 2009) (Kraakman et al., 2004). Karakteristik ini berlaku pula di Indonesia, sebagaimana tertuang dalam Pasal 3 Undang-Undang No. 40 Tahun 2007 tentang Perseroan Terbatas (Republik Indonesia, 2007) yang menyatakan bahwa perikatan yang dibuat perseroan tidak menjadikan pemilik saham memiliki tanggungjawab secara pribadi dan apabila perusahaan mengalami kerugian, maka pemilik saham bertanggung jawab hanya sebatas jumlah saham yang dimiliki.

(Hill \& Jones, 2012) menjelaskan bahwa siklus hidup suatu industri secara umum terdiri atas tahapan-tahapan diantaranya embryonic, tumbuh dan berkembang (growth), guncangan (shakeout), dewasa (mature), dan diakhiri dengan tahapan tiada (decline). Penggunaan siklus hidup industri relevan karena kumpulan dari korporasi yang sejenis akan membentuk industri tertentu. Pada tahapan tiada (decline), proses pembubaran dan likuidasi terjadi. Terkait pembubaran korporasi, konsekuensi dari berlakunya prinsip separate patrimony, sebuah korporasi tidak dapat dibubarkan dengan begitu saja, namun perlu terdapat proses likuidasi untuk menyelesaikan seluruh hak dan kewajiban korporasi sebelum badan hukumnya dibubarkan. Di Indonesia, banyak korporasi yang telah memasuki proses likuidasi dan pembubaran. Di sektor perbankan saja misalnya, ada 95 bank dalam likuidasi terhitung sejak 2006 hingga februari 2019 (Lembaga Penjamin Simpanan, 2019).

Dari sisi akuntansi dan pelaporan keuangan, Standar Akuntansi Keuangan (SAK) di Indonesia belum mengatur secara spesifik terkait likuidasi korporasi. Hal ini berbeda dengan sektor pemerintahan, di mana likuidasi entitas akuntansi dan entitas pelaporan pada Kementerian/Lembaga telah diatur melalui Peraturan Menteri Keuangan Nomor 48/PMK.05/2017 (Republik Indonesia, 2017). Dalam Pernyataan Standar Akuntansi Keuangan (Dewan Standar Akuntansi Keuangan, 2015) tentang Penyajian Laporan Keuangan, korporasi sebagai entitas akuntansi menyusun laporan keuangan berdasarkan asumsi kelangsungan usaha (going concern) kecuali apabila manajemen memiliki intensi untuk melikuidasi entitas atau menghentikan perdagangan. Selanjutnya, apabila entitas menyusun laporan keuangan tidak berdasarkan asumsi kelangsungan usaha, maka entitas perlu mengungkapkan beberapa hal seperti dasar yang digunakan serta alasannya. Dengan demikian, dapat dikatakan bahwa dalam kondisi tertentu PSAK 1 (Dewan Standar Akuntansi Keuangan, 2015) memperbolehkan pelaporan dengan asumsi selain asumsi kelangsungan usaha. Namun demikian, PSAK 1 (Dewan Standar Akuntansi Keuangan, 2015) tidak memberikan fasilitas aturan yang digunakan sebagai alternatif dalam hal terdapat kondisi seperti likuidasi korporasi. Oleh karena itu, entitas diberikan kebebasan untuk menggunakan alternatif asumsi akuntansi yang dapat menghasilkan informasi keuangan yang paling relevan dan andal. Salah satu alternatif akuntansi selain akuntansi basis kelangsungan usaha yang kerap digunakan oleh korporasi dalam pembubaran adalah akuntansi basis likuidasi.

Dari sisi prosedur likuidasi, terdapat UUPT yang mengatur tentang pembubaran, likuidasi, dan berakhirnya status badan hukum perseroan. Aturan mengenai pembubaran 
sebuah korporasi harus diikuti dengan likuidasi diatur dalam pasal 142 UUPT, akan tetapi UUPT belum mengatur secara eksplisit mengenai mekanisme pembubaran Perseroan Terbatas tersebut (Ikhrami, 2017).

Penelitian sebelumnya di Indonesia yang mengulas topik likuidasi korporasi masih terbatas. (Ikhrami, 2017) menemukan bahwa dalam melaksanakan tugasnya, peran likuidator terbit dari suat hubungan antara likuidator dengan pihak lain atau khususnya organ perseroan terbatas. Pelaksanaan pembubaran perseroan terbatas dengan likuidasi melahirkan hak dan kewajiban bagi pemegang saham dan likuidator. Selanjutnya, (Permatasari, 2015) menyimpulkan bahwa peraturan pasar modal terkait dengan reksadana dan kontrak investasi kolektif sudah cukup melindungi hak-hak dari pemegang unit penyertaan dalam hal reksa dana berbentuk kontrak investasi kolektif dibubarkan. Sementara itu, (Kumalasari, 2016) menyimpulkan bahwa perlindungan hukum secara eksplisit mengenai jangka waktu likuidasi tidak ada kepastian hukum karena tidak ada aturan yang mengatur. Penelitian-penelitian tersebut, mengulas likuidasi korporasi dari sisi aspek hukum. Namun, berdasarkan reviu literatur yang telah dilakukan, masih belum terdapat penelitian yang mengulas likuidasi korporasi dari sudut pandang akuntansi. Adapun penelitian akuntansi yang telah dilakukan hanya sebatas topik financial distress seperti yang dilakukan oleh (Iswandi, 2012), (Safitra, Kertahadi, \& Handayani, 2013), (Junaidi, 2016), (Wulandari, Burhanudin, \& Widayanti, 2017) dan (Buari, Istiatin, \& Djumali, 2017).

Berdasarkan uraian di atas, penelitian ini mencoba untuk mengulas likuidasi korporasi dari sisi akuntansi. Penelitian ini menggunakan proses likuidasi yang terjadi pada Reksa Dana Terproteksi TRAM Terproteksi Prima XI yang merupakan produk dari PT. Trimegah Asset Management, dimana PT. Trimegah Asset Management itu sendiri merupakan anak PT. Trimegah Sekuritas Indonesia Tbk. TRAM Terproteksi Prima XI memberikan proteksi $100 \%$ (seratus per seratus) terhadap pokok investasi pada tanggal pelunasan akhir serta memberikan investor imbal hasil reguler dari efek bersifat utang yang diterbitkan oleh korporasi berbadan hukum Indonesia yang telah diperingkat oleh perusahaan pemeringkat yang terdaftar di OJK (Otoritas Jasa Keuangan) dan masuk dalam kategori layak investasi (investment grade). Komposisi investasi TRAM terproteksi prima XI berupa efek bersifat uang dengan persentase 80 $100 \%$, dan Instrumen Pasar Uang 0 - 20\%. (www.trimegah-am.com).

\section{TINJAUAN PUSTAKA}

Menurut (Munn, Garcia, \& Woelfel, 1994), likuidasi memiliki 3 (tiga) pengertian. Pertama, realisasi kas, di mana terjadi penjualan kepemilikan saham, obligasi, atau komoditas, yang dilakukan baik untuk mengambil keuntungan, untuk antisipasi, atau untuk mencegah kerugian karena harga yang lebih rendah. Kedua, pengakhiran atau penutupan bisnis dengan mengonversi asetnya menjadi uang tunai dan distribusi hasil dimana yang pertama diberikan kepada kreditor sesuai urutan preferensi dan sisanya kepada pemilik sesuai proporsi kepemilikan mereka. Ketiga, salah satu prosedur pertolongan yang tersedia bagi debitur yang pailit, dimana likuidasi memiliki tujuan dasar realisasi aset dan kewajiban dibanding kelanjutan bisnis seperti dalam reorganisasi. Sementara itu, (Beams, Anthony, Bettinghaus, \& Smith, 2014) menyatakan bahwa dalam likuidasi korporasi terdapat trustee (curator) yang memiliki kewajiban mengubah aset korporasi menjadi uang tunai, dan mendistribusikan hasilnya sesuai dengan prioritas klaim.

Berdasarkan UUPT Pasal 142 ayat 1 menjelaskan penyebab terjadinya pembubaran perseroan dan pada ayat 2 pasal tersebut dijelaskan lebih lanjut bahwa pembubaran tersebut dilanjutkan dengan proses likuidasi dan dalam periode 
pembubaran perseroan, perseroan tidak diperkenankan melakukan perbuatan hukum kecuali untuk urusan likuidasi. Untuk beberapa sebab tertentu pembubaran perseroan, pasal 142 ayat 3 memberikan opsi berupa direksi bertindak sebagai likuidator ketika RUPS tidak menetapkan likuidator. Pada pasal 143 ayat 1 dapat dikatakan bahwa undang-undang menjamin perseroan tidak kehilangan status badan hukum selama proses likuidasi, namun dalam ayat 2 pasal tersebut mengisyaratkan untuk mencantumkan penulisan "dalam likuidasi" dibelakang nama perseroan untuk keperluan persuratan.

Pasal 144 ayat 1 memberikan fasilitas kepada Direksi, Dewan Komisars, dan Pemegang saham untuk mengusulkan pembubaran perseroan kepada RUPS, dengan syarat harus mewakili sedikitnya $10 \%$ dari jumlah saham dengan hak suara. Pada Pasal 147 ayat 1, dijelaskan kewajiban likuidator untuk memberitahukan pembubaran perseroan kepada semua kreditor dan kepada menteri dengan cara yang telah ditetapkan, dan apabila belum dilakukan, pasal 148 ayat 1 menegaskan ketidakberlakuan pembubaran tersebut untuk pihak ketiga. Selain itu, apabila likuidator lalai, maka likuidator menerima tanggung jawab renteng atas kerugian pihak ketiga sebagaimana dijelaskan pasal 148 ayat 2. Pasal 149 ayat 1 menjelaskan kewajiban likuidator dalam proses likuidasi, dan pada ayat 2 diberikan opsi kepada likuidator untuk mengajukan pailit apabila diperkirakan kekayaan perseroan tidak mencukupi untuk menutupi utang perseroan.

Ditinjau dari Peraturan Pemerintah No. 27 Tahun 1998 tentang Penggabungan, Peleburan, dan Pengambilalihan Perseroan Terbatas (Republik Indonesia, 1998), dalam Pasal 2 menegaskan bahwa penggabungan dan peleburan korporasi dapat dilakukan tanpa likuidasi. Sebagai akibatnya, pasal 3 menjelaskan bahwa pemegang saham yang menggabungkan atau meleburkan akan menjadi pemegang saham yang menerima penggabungan dan peleburan serta aktiva dan pasiva perseroan akan beralih karena hukum.

FASB Accounting Standards Codification Topic 205 tentang Liquidation Basis of Accounting (FASB Accounting Standards Codification, 2013), diatur tambahan ketentuan sebagai transisi dari paragraph 205-30-65-1, diatur bahwa Proses di mana entitas mengubah asetnya menjadi uang tunai atau aset lainnya dan menyelesaikan kewajibannya dengan kreditor sebagai antisipasi dari entitas yang semua kegiatannya terhenti dan setelah penghentian kegiatan entitas, sisa uang tunai atau aset lainnya didistribusikan ke investor entitas atau penuntut lainnya. Lebih lanjut dijelaskan likuidasi bisa jadi wajib atau sukarela serta ditegaskan bahwa disolusi dari suatu entitas sebagai hasil dari entitas yang diakuisisi oleh entitas lain atau digabung menjadi entitas lain secara keseluruhan dan dengan harapan melanjutkan bisnisnya tidak memenuhi syarat sebagai likuidasi. Selanjutnya, adanya pernyataan perubahan aset bersih dalam likuidasi dengan arti bahwa yang menyajikan perubahan selama periode dalam aset bersih tersedia untuk distribusi kepada investor dan penuntut lainnya selama likuidasi. Selain itu, adanya pernyataan aset neto dalam likuidasi, yakni menyajikan aset bersih entitas yang melikuidasi tersedia untuk distribusi kepada investor dan penuntut lainnya pada akhir periode pelaporan.

\section{METODE PENELITIAN}

Penelitian ini menggunakan metode kualitatif. Adapun pemilihan Reksa Dana Terproteksi TRAM Terproteksi Prima XI sebagai objek penelitian karena Reksa Dana Terproteksi TRAM Terproteksi Prima XI menggunakan basis likuidasi untuk tahun 2015 pada laporan keuangan audited, sehingga objek penelitian sesuai dengan bahasan. Selain itu, terdapat prospektus Reksa Dana Terproteksi TRAM Terproteksi Prima XI 
yang menjelaskan prosedur likuidasi, sehingga mudah untuk dilakukan analisa sesuai dengan ketentuan yang berlaku pada UUPT. Teknik analisis data dilakukan dengan cara menganalisis prospektus Reksa Dana Terproteksi TRAM Terproteksi Prima XI dan data laporan keuangan audited TRAM Terproteksi Prima XI tanggal 31 Desember 2015 (Basis Likuidasi) dan 2014 (Basis Kelangsungan Usaha). Selanjutnya, analisis dilakukan menggunakan kesesuaian berdasarkan informasi dalam SAK dan UUPT.

\section{HASIL DAN PEMBAHASAN}

Berdasarkan prosedur dan tata cara likuidasi korporasi, maka dijelaskan bahwa Prospektus Reksa Dana Terproteksi TRAM Terproteksi Prima XI, TRAM Terproteksi Prima XI wajib dibubarkan, apabila terjadi salah satu dari kondisi berikut. Pertama, apabila memiliki dana kelolaan kurang dari 25 milyar dalam kurun waktu 90 hari bursa dan telah efektifnya pernyataan pendaftaran. Kedua, apabila ada perintah OJK sesuai aturan yang berlaku. Kondisi yang ketiga adalah nilai aktiva kurang dari 25 milyar dalam kurun waktu selama 90 hari bursa secara berturut-turut. Kondisi yang terakhir adalah adanya kesepakatan antara manajer investasi dan bank kustodian telah sepakat untuk pembubaran.

Apabila kondisi pertama terjadi, maka manajer investasi berkewajiban melaporkan hal tersebut kepada OJK dan membuat pengumuman kepada para pemegang unit penyertaan dengan cara yang ditetapkan. Atas instruksi manajer investasi, pembayaran dana hasil likuidasi dilakukan bank kustodian dengan proporsional kepada pemegang unit penyertaan. Selanjutnya, manajer investasi melakukan pembubaran dan kepada OJK disampaikan laporan hasil pembubaran. Untuk kondisi ketiga dan keempat, prosedur yang dilakukan manajer investasi mirip dengan kondisi pertama namun yang terlihat berbeda pada kewajiban menyampaikan lampiran laporan pada saat melakukan pelaporan kondisi pada OJK, pemberitahuan secara tertulis untuk menghentikan perhitungan nilai aktiva bersih kepada bank kustodian, dan laporan hasil kepada OJK yang dilengkapi dengan pendapat serta akta pembubaran dan likuidasi. Adapun untuk kondisi kedua mirip dengan kondisi ketiga dan keempat, namun yang membedakan adalah tidak ada kewajiban pelaporan kondisi pada OJK.

Dalam Prospektus Reksa Dana Terproteksi TRAM Terproteksi Prima XI lebih banyak menjelaskan mengenai kewajiban manajer investasi dalam prosedur dan tata cara likuidasi Reksa Dana Terproteksi TRAM Terproteksi Prima XI. Manajer investasi dalam bab 3 Prospektus Reksa Dana Terproteksi TRAM Terproteksi Prima XI adalah PT. Trimegah Asset Management yang telah memperoleh izin usaha sebagai manajer investasi berdasarkan Surat Keputusan BAPEPAM dan LK No. 02/BL/MI/2011 tanggal 31 januari 2011.

Dengan analisa perbandingan antara Prospektus Reksa Dana Terproteksi TRAM Terproteksi Prima XI dan UUPT, terlihat bahwa UUPT mengatur tentang bagaimana likuidator berperan serta kewajibannya dalam pelaksanaan pembubaran dan likuidasi korporasi, sedangkan Prospektus Reksa Dana Terproteksi TRAM Terproteksi Prima XI lebih banyak berbicara tentang kewajiban manajer investasi dalam prosedur dan tata cara likuidasi daripada peran likuidator itu sendiri. Selain itu, Prospektus Reksa Dana Terproteksi TRAM Terproteksi Prima XI menjelaskan pelaporan hasil pembubaran, likuidasi, dan pembagian hasil likuidasi kepada OJK, dimana dalam UUPT tidak diatur peran serta OJK dalam proses likuidasi. Oleh karena itu, dapat dikatakan bahwa Reksa Dana Terproteksi TRAM Terproteksi Prima XI menerapkan prosedur yang lebih rinci dibandingkan dengan UUPT yang hanya mengatur prosedur dan tata cara likuidasi secara praktis, namun rincian proses pembubaran dan likuidasi di korporasi yang 
dilaksanakan ternyata lebih luas dibandingkan proses pembubaran dan likuidasi yang diatur di UUPT.

Berdasarkan akuntansi likuidasi yang diterapkan, laporan keuangan audited TRAM Terproteksi Prima XI tanggal 31 Desember 2015 (Basis Likuidasi) dan 2014 (Basis Kelangsungan Usaha) serta untuk tahun-tahun yang berakhir pada tanggal tersebut menjelaskan bahwa adanya kesepakatan untuk membubarkan dan melikuidasi Reksa Dana Terproteksi TRAM Terproteksi Prima XI karena efek utang telah jatuh tempo tanggal 15 oktober 2016. Oleh karena itu, manajer investasi dan bank kustodian telah melakukan perubahan basis akuntansi dari basis akuntansi kelangsungan usaha menjadi basis akuntansi likuidasi dalam rangka penyusunan dan pengukuran laporan keuangan Reksa Dana Terproteksi TRAM Terproteksi Prima XI efektif tanggal 31 Desember 2015.

Perubahan basis akuntansi dari basis kelangsungan usaha menjadi basis likuidasi, membuat Reksa Dana Terproteksi TRAM Terproteksi Prima XI harus mengikuti standar pelaporan basis likuidasi. Namun, SAK di Indonesia sendiri belum mengatur terkait pelaporan akuntansi basis likuidasi. Dari pelaporan keuangan audited TRAM Terproteksi Prima XI tanggal 31 Desember 2015 (Basis Likuidasi) dan 2014 (Basis Kelangsungan Usaha) serta untuk tahun-tahun yang berakhir pada tanggal tersebut, khususnya dalam laporan posisi keuangan, terlihat bahwa setelah akun "utang lain-lain", dituliskan kelanjutannya dengan "aset neto yang dapat diatribusikan kepada pemegang unit", kemudian "jumlah unit penyertaan beredar" dan diakhiri dengan "nilai aset neto yang dapat diatribusikan kepada pemegang unit per unit penyertaan".

Selanjutnya, laporan posisi keuangan yang dibuat oleh Reksa Dana Terproteksi TRAM Terproteksi Prima XI sesuai dengan FASB Accounting Standards Codification Topic 205 tentang Liquidation Basis of Accounting (FASB Accounting Standards Codification, 2013), sebagaimana diatur dalam tambahan ketentuan sebagai transisi dari paragraf 205-30-65-1. Hal ini dimungkinkan bahwa SAK di Indonesia belum mengatur laporan keuangan basis likuidasi korporasi seperti yang terjadi pada Reksa Dana Terproteksi TRAM Terproteksi Prima XI. Ketiadaan aturan basis likuidasi dalam SAK di Indonesia, mengakibatkan Reksa Dana Terproteksi TRAM Terproteksi Prima XI secara best practices mengikuti standar yang diatur secara internasional yang diatur oleh FASB Accounting Standards Codification Topic 205 tentang Liquidation Basis of Accounting (FASB Accounting Standards Codification, 2013). Oleh karena itu, Reksa Dana Terproteksi TRAM Terproteksi Prima XI dapat melaporkan laporan posisi keuangan kedalam basis likuidasi berdasarkan standar tersebut.

\section{SIMPULAN}

Penelitian ini menyimpulkan bahwa Reksa Dana Terproteksi TRAM Terproteksi Prima XI menerapkan prosedur yang lebih rinci dibandingkan dengan UUPT yang hanya mengatur prosedur dan tata cara likuidasi secara praktis. Hal ini terlihat dari Prospektus Reksa Dana Terproteksi TRAM Terproteksi Prima XI yang lebih menjelaskan kewajiban dari manajer investasi dalam proses likuidasi dibanding peran likuidator itu sendiri serta menjelaskan pelaporan hasil pembubaran, likuidasi, dan pembagian hasil likuidasi kepada OJK. Selain itu, SAK belum mengatur laporan keuangan basis likuidasi korporasi seperti yang terjadi pada Reksa Dana Terproteksi TRAM Terproteksi Prima XI. Masih belum adanya aturan mengenai basis likuidasi dalam SAK di Indonesia, membuat Reksa Dana Terproteksi TRAM Terproteksi Prima XI secara best practices mengikuti standar yang diatur secara internasional mengenai laporan keuangan basis likuidasi seperti yang diatur oleh FASB Accounting Standards Codification Topic 205 tentang Liquidation Basis of Accounting (FASB Accounting 
Standards Codification, 2013). Dengan demikian, Reksa Dana Terproteksi TRAM Terproteksi Prima XI dapat melaporkan laporan posisi keuangan kedalam basis likuidasi.

Keterbatasan dalam penelitian ini adalah adalah objek dalam tulisan hanya memfokuskan pada Reksa Dana Terproteksi TRAM Terproteksi Prima XI yang merupakan salah satu korporasi di Indonesia yang yang memiliki informasi terkait dengan pembubaran dan likuidasi korporasi, sehingga tidak mencerminkan penerapan SAK dan Prosedur likuidasi korporasi secara keseluruhan.

Berdasarkan keterbatasan tersebut, penelitian selanjutnya diharapkan dapat memperluas objek dengan tidak hanya terbatas menggunakan data satu korporasi, namun dapat menggunakan beberapa korporasi atau bidang usaha korporasi sehingga lingkup bahasan dapat menjadi lebih luas. Selain itu, bahasan dalam penelitian ini hanya mendasarkan pada data laporan keuangan audited TRAM Terproteksi Prima XI tanggal 31 Desember 2015 (Basis Likuidasi) dan 2014 (Basis Kelangsungan Usaha) serta untuk tahun-tahun yang berakhir pada tanggal tersebut, serta data Prospektus Reksa Dana Terproteksi TRAM) yang telah dikeluarkan. Untuk penelitian selanjutnya dapat mengunakan teknik wawancara secara langsung kepada korporasi yang mengalami likuidasi, ahli hukum, likuidator, kurator dan praktisi akuntansi terkait best practices dalam pembubaran dan likuidasi korporasi untuk memberikan pembahasan yang lebih komprehensif. Selanjutnya, Ikatan Akuntan Indonesia selaku Badan Penyusun SAK di Indonesia perlu mengatur akuntansi untuk pembubaran korporasi di Indonesia yang dapat digunakan oleh korporasi-korporasi yang mengalami proses likuidasi.

\section{DAFTAR PUSTAKA}

Badan Pusat Statistik. (2016). Hasil Pendaftaran Usaha/Perusahaan Sensus Ekonomi 2016 Indonesia.

Beams, F. A., Anthony, J. H., Bettinghaus, B., \& Smith, K. A. (2014). Advanced Accounting Twelfth Edition (Global Edi.). United Kingdom: Pearson.

Buari, D. I. R., Istiatin, \& Djumali. (2017). Analisis tingkat kebangkrutan pada perusahaan manufaktur di Bursa Efek Indonesia. Jurnal Bisnis dan Ekonomi, 23(1), 24-32.

Dewan Standar Akuntansi Keuangan. (2015). PSAK No. 1 (Revisi 2015): Penyajian Laporan Keuangan. Jakarta: IAI.

FASB Accounting Standards Codification. (2013). Presentation of Financial Statements (Topic 205) Liquidation Basis of Acccounting. Norwalk: FASB of the Financing Accounting Foundation.

Hill, C. W. L., \& Jones, G. R. (2012). Strategic Management An Integrated Approach (tenth edit.). Canada: Nelson Education, Ltd.

Ikhrami, Y. (2017). Pelaksanaan pembubaran perseroan terbatas yang diikuti dengan likuidasi oleh likuidator berdasarkan Undang-Undang Nomor 40 Tahun 2007. Universitas Andalas: Tesis Magister Kenotariatan.

Iswandi, I. (2012). Analisis Potensi Kebangkrutan PT. Berlian Laju Tanker, Tbk. dengan Menggunakan Altman's Z Score. Binus Business Review, 3(2), 654. Retrieved from https://journal.binus.ac.id/index.php/BBR/article/view/1350

Junaidi, J. (2016). PENGUKURAN TINGKAT KESEHATAN DAN GEJALA FINANCIAL DISTRESS PADA BANK UMUM SYARIAH DI INDONESIA. KINERJA, 20(1), 42-52. Retrieved from http://ojs.uajy.ac.id/index.php/kinerja/article/view/696

Kraakman, R., Armour, J., Davies, P., Enriques, L., Hansmann, H., Hertig, G., Hopt, K., et al. (2004). The anatomy of corporate law: a comparative and functional 
approach. Oxford: Oxford University Press.

Kraakman, R., Armour, J., Davies, P., Enriques, L., Hansmann, H., Hertig, G., Hopt, K., et al. (2009). The anatomy of corporate law: a comparative and functional approach. Oxford: Oxford University Press.

Kumalasari, E. D. (2016). Perbandingan Perlindungan Hukum Bank dilikuidasi dan Bank Pailit dalam Pengembalian Dana. Universitas Brawijaya: Skripsi Ilmu Hukum.

Munn, G. G., Garcia, F. L., \& Woelfel, C. J. (1994). Encyclopedia Of Banking \& Finance Tenth Edition. Chicago: Probus Publishing Company.

Permatasari, N. (2015). Analisa hukum tanggung jawab manajer investasi dan bank kustodian pada pembubaran reksa dana berbentuk kontrak investasi kolektif dalam kaitannya dengan kepentingan unit penyertaan. Universitas Gajah Mada: Tesis Magister Ilmu Hukum.

Republik Indonesia. (1998). Peraturan Pemerintah No. 27 Tahun 1998 tentang Penggabungan, Peleburan, dan Pengambilalihan Perseroan Terbatas. Jakarta: Sekretariat Negara.

Republik Indonesia. (2007). Undang-Undang Republik Indonesia No 40 Tahun 2007 tentang Perseroan Terbatas. Jakarta: Sekretariat Negara.

Republik Indonesia. (2017). Peraturan Menteri Keuangan No. 48/PMK.05/2017 tentang Pelaksanaan Likuidasi Entitas Akuntansi dan Entitas Pelaporan.

Safitra, B. A., Kertahadi, \& Handayani. (2013). Analisis metode altman (z-score) sebagai alat evaluasi guna memprediksi kebangkrutan perusahaan (studi pada industry rokok yang terdaftar di BEI periode 2007-2011). Universitas Brawijaya: Fakultas Ilmu Administrasi.

Wulandari, F., Burhanudin, B., \& Widayanti, R. (2017). Analisis Prediksi Kebangkrutan Menggunakan Metode Altman (Z-Score) Pada Perusahaan Farmasi (Studi Kasus Pada Perusahaan yang Terdaftar di Bursa Efek Indonesia Tahun 2011 - 2015). Benefit: Jurnal Manajemen dan Bisnis, 2(1), 15. Retrieved from http://journals.ums.ac.id/index.php/benefit/article/view/3237 